\title{
microRNAs and lung cancer: tumors and 22-mers
}

\author{
Liqin $\mathrm{Du}^{1}$ and Alexander Pertsemlidis ${ }^{1,2}$ \\ ${ }^{1}$ Harold C. Simmons Comprehensive Cancer Center, The University of Texas Southwestern \\ Medical Center, 5323 Harry Hines Boulevard, Dallas, TX 75390, USA \\ 2 Eugene McDermott Center for Human Growth and Development and the Department of Internal \\ Medicine, The University of Texas Southwestern Medical Center, 5323 Harry Hines Boulevard, \\ Dallas, TX 75390, USA
}

\section{Keywords \\ microRNA; lung cancer}

\section{Introduction}

miRNAs are a class of short, 19 to 25 nucleotide long RNAs that regulate gene expression by binding to sequences in the $3^{\prime}$ untranslated region (3' UTR) of an expressed mRNA, resulting in either modulation of translation efficiency or degradation of the mRNA [1-3]. To date, there are $~ 700$ annotated human miRNA loci that form short stem-loop structures when transcribed and produce either one or two mature miRNAs. Mature miRNAs are typically only partially complementary to their target mRNAs, meaning that each miRNA can regulate a broad set of targets. miRNAs have been shown to regulate expression of a variety of genes involved in cell proliferation, differentiation, apoptosis, stem cell development, and human disease. Recent studies have demonstrated the critical role of miRNAs in cancer pathogenesis [4-10]. The potential of restoring levels of aberrantly under-expressed miRNAs with miRNA mimics or inactivating over-expressed miRNAs with miRNA inhibitors has been explored and shows promise as the next generation of therapeutic strategies [11-15]. More recently, miRNAs have been detected in peripheral blood [16-19], which also makes them attractive candidates as biomarkers for non-invasive and early cancer detection.

Conventional wisdom in the field of oncology suggests that the development and progression of malignant neoplasias involve multiple genetic changes, each of which can result in the disregulation of crucial pathways involved in cellular processes such as growth, proliferation, and survival. The accumulation of these genetic alterations confers a malignant phenotype that can be described by six primary hallmarks of cancer: unlimited cell proliferation, autonomous growth without the need for external signals, resistance to growth inhibitory signals, escape from apoptosis (programmed cell death), the ability to recruit new vasculature (neoangiogenesis), and increased tissue invasion and metastasis [20]. Over the past 30 years, many genes have been implicated in malignant transformation, with altered expression or function contributing to one or more of the six hallmarks of cancer. Although the roles of many genes in tumorigenesis have been clearly defined, the mechanisms by which they are altered in cancer development have not been completely understood. Recent work has revealed novel regulatory mechanisms in pathological disease states that are mediated by miRNAs and has

Alexander Pertsemlidis, McDermott Center for Human Growth and Development, The University of Texas Southwestern Medical Center, 5323 Harry Hines Boulevard, Dallas, TX 75390-8591, Tel.: (214) 648-1921, Fax: (214) 648-1666,

Alexander.Pertsemlidis@UTSouthwestern.edu. 
inspired researchers to begin defining the specific roles of miRNAs in the regulation of genes involved in cancer development and progression, a process that will provide researchers and clinicians with new therapeutic tools and targets. Although we are far from full elucidation of these relationships, important clues have already emerged that implicate the altered expression of these enigmatic molecules as critical to the process of tumorigenesis.

Here we review recent advances in the study of miRNAs involved in tumorigenesis, focusing on miRNA regulation of genes that have been demonstrated to play critical roles in lung cancer development. Current progress in the development of miRNA-based diagnostics and therapeutics will also be discussed.

\section{miRNA regulation of the intracellular processes controlling cancer cell survival and growth}

Of the six major hallmarks of cancer summarized by Hanahan and Weinberg, four of them unlimited cell proliferation, autonomous growth, resistance to growth inhibitory signals, and escape from apoptosis - are central to the transformation of a normal cell to a cancer phenotype, the initial step of tumorigenesis. Many genes have been demonstrated to affect one or more of these four rate-limiting processes. Normal cell growth is tightly controlled to maintain homeostasis through a finely tuned balance of mitogenic and anti-proliferative signal cascades. The concerted action of critical cell cycle molecules such as RAS, the cell cycle regulator phosphatase and tensin homolog (PTEN), MYC, and Abl normally keeps cellular proliferation under control; altered expression of key regulators can disrupt this balance and promote deregulated growth. Programmed cell death (apoptosis) is a critical cellular process that normally serves to maintain cell proliferative homeostasis and prevent the unrestricted division of cells [21]. Disruption of apoptotic processes can allow genetically unstable cells to bypass programmed cell death, thereby allowing them to accumulate further mutations that can result in tumorigenesis. miRNAs have recently been implicated as important modulators of cell growth and survival processes, and disregulation of these molecules can initiate malignant transformation and unchecked cellular growth.

\section{miRNA regulation of growth factor receptors}

Altered expression of cell surface growth factor receptors such as receptor tyrosine kinases (RTKs) is the major mechanism that leads to the self-sufficient growth of cancer cells, and is often a primary phenotypic characteristic of many malignancies, including lung cancers. This paradigm has served as the basis for the development of targeted cancer therapies. Members of the ErbB family of RTKs, such as the epidermal growth factor receptor (EGFR, ErbB1), ErbB2, and ErbB3, can initiate signal cascades leading to DNA synthesis and cell proliferation, and overexpression of these receptors is often critically involved in tumorigenesis and cancer cell proliferation [22]. Rapidly accumulating evidence suggests that miRNAs could be critically involved in the regulation of RTKs in certain tumor types. For example, ErbB2 and ErbB3 are implicated in cell proliferation in breast cancers that over-express these proteins, and the expression of miR-125a and miR-125b has been shown to down-regulate the expression and activity of these receptors in a breast cancer cell line [23]. EGFR has shown marked overexpression in several tumor types, including lung cancer, and has been the focus of several targeted agents designed to suppress its activity in lung cancer and other malignancies. Recent investigations have demonstrated that miRNAs are likely to be involved in the regulation of EGFR in lung cancer. An inhibitor of miR-128b resulted in up-regulated EGFR expression in an EGFR-expressing NSCLC cell line, and treatment with a miR-128b mimic resulted in a concomitant reduction of EGFR expression [24]. Furthermore, clinical analysis of 58 patients with NSCLC who were treated with gefitinib, a small molecule tyrosine kinase inhibitor against EGFR, showed that loss of miR-128b was significantly associated with improved disease 
control following treatment $(\mathrm{p}=0.03)$, and improved survival (23.4 versus 10.5 months, $\mathrm{p}=$ 0.02) [24]. The let-7 miRNA was also shown to reduce EGFR mRNA and protein expression in several cancer cell lines, including those derived from lung, suggesting a role in the regulation of cellular processes involved in lung cancer initiation and progression [25].

The above and other studies [26,27] clearly indicate that miRNA regulation can contribute to the aberrant expression of growth factor receptors leading to the uncontrolled growth of tumor cells. However, the significance of some of these regulations, such as regulation of PDGF by miR-140 [26] in lung cancer development, has not yet been evaluated.

\section{miRNA regulation of proto-oncogenes RAS and MYC}

The proto-oncogene RAS is the central molecule of the SOS-RAS-Raf-MAPK cascade, which is the downstream cytoplasmic effector of the growth factor receptors. Approximately $20 \%$ of tumors in general and $30 \%$ of lung tumors have activating mutations in one of the RAS genes [28]. These mutations can contribute to several aspects of the malignant phenotype, including disregulated cell growth [29]. The MYC oncogene is one of the downstream effectors of the RAS signaling pathway. MYC amplification and over-expression has been detected of different histologic subtypes of lung cancer [30]. Both RAS and MYC are targets of the let-7/miR-98 family of miRNAs. Johnson, et al showed that members of the let-7 family of miRNAs bind to the $3^{\prime}$ UTR of RAS, down-regulating RAS expression in human cells, that let-7 is poorly expressed in lung cancer compared to normal lung tissue, and that the expression of let-7 is inversely correlated with the expression of RAS in lung tumor samples [31]. Kumar et al. showed that over-expression of let-7 inhibited the growth of k-RAS expressing lung cancer cells in vitro, inducing cell cycle arrest and cell death [32], and that induced over-expression of let- $7 \mathrm{~g}$ resulted in significant reduction of tumor growth in a lung cancer xenograft model. In another study, let-7a was independently shown to down-regulate MYC and reverted MYCinduced growth in Burkitt lymphoma cells $[33,34]$. Together, these data suggest that overexpression of RAS and MYC due to let-7 down-regulation could be a primary mediator of tumor cell proliferation, and that let-7 family members could be important markers of tumorigenic processes.

\section{miRNA regulation of replicative potential}

Maintenance of telomeric DNA is one of the mechanisms leading to unlimited replicative potential. The ability of cancer cells to replicate indefinitely (immortalization) is related to their ability to maintain telomere length, either through the down-regulation of telomerase, by lengthening telomeres through the activity of human telomere reverse transcriptase (hTERT), or through alternative lengthening of telomeres (ALT) which occurs through the process of recombination-mediated elongation [35]. Several miRNAs have been implicated in the regulation of genes involved in maintaining telomere length. A non-significant inverse correlation between hTERT and miR-138 expression was observed in thyroid cancer cell lines, with miR-138 down-regulated in tumor cells relative to normal tissues [36]. DNA methyltransferases (DNMTs) have been recently shown to play critical roles in controlling telomere length [37]. Deficiency in Dicer1, the cytoplasmic ribonuclease that processes precursor miRNAs into short double-stranded RNAs, leads to decreased expression of DNA methyltransferases and increased telomere elongation in a retinoblastoma-like 2 protein (Rbl-2)-dependent manner, with Rbl-2specifically targeted and down-regulated by members of the miR-290 family [38]. In lung cancer cell lines, forced expression of members of the miR-29 family decreases the expression of DNMT3A and -3B, two DNMTs that have been shown to control telomere length and recombination in mammalian cells, and restores normal methylation patterns [39]. An inverse correlation between expression of miR-29s and that of DNMT3A and -3B was also observed in lung cancer tissues. 
Although the significance of miRNA regulation of telomere length has not been fully evaluated in in vivo studies, the current data suggest that miRNAs could affect telomere homeostasis and elongation, and that the altered expression of miRNAs regulating this pathway could potentially contribute to the unlimited replicative potential of cancer cells.

\section{miRNA regulation of apoptotic pathways}

Defects in apoptosis occur in over half of malignant tumors, predominantly due to up-regulation of the anti-apoptotic Bcl-2 proteins or to mutations in the p53 tumor suppressor [40]. The miR-15/miR-16 cluster of miRNAs has been shown to negatively regulate the expression of Bcl-2 at the post-transcriptional level, with this cluster of regulatory elements frequently deleted or otherwise down-regulated in a variety of tumor types [41-43]. Up-regulation of Bcl-2 protein through decreased expression of these miRNAs could therefore be a major determinant of malignant transformation, and that exogenous administration of these regulatory elements could provide a therapeutic benefit in miR-15/16-deficient cancers. A study in cholangiocarcinoma cells showed that miR-29 directly targets and down-regulates the expression of Mcl-1 protein [44], a member of the Bcl-2 family of anti-apoptotic proteins that has been found to be over-expressed in a number of human cancers. miR-29 is down-regulated in a number of human cancers including lung cancers, and its ability to repress Mcl-1 coupled with its role in regulating epigenetic DNA methylation [39] means that artificially enhanced expression of this regulatory element could be an effective therapeutic strategy $[16,45,46]$.

miR-21 is an anti-apoptotic miRNA that was first identified as an antagonist of programmed cell death in glioblastoma cells. miR-21 levels were shown to be elevated in glioblastoma tissues, with knockdown of miR-21 resulting in caspase activation and apoptosis in vitro [47]. Oligonucleotides inhibitors of miR-21 were also shown to increase apoptosis in a breast cancer xenograft model, an effect that was likely due to down-regulation of Bcl-2[15]. Inhibition of miR-21 was recently shown to enhance the anti-apoptotic potential of an antiEGFR tyrosine kinase inhibitor in an EGFR-mutant lung adenocarcinoma cell line [48]. Members of the miR-34 family of miRNAs are under-expressed in a variety of tumors [4], and have been implicated in the regulation of apoptosis, depending on the context in which they are expressed. In lung cancer cells, induction of miR-34 results in apoptosis [49,50], and miRNA profiling shows that the expression of miR-34a, miR-34b and miR-34c are directly correlated with expression of the p53 tumor suppressor [51], suggesting that miR-34 is involved in regulating apoptosis as a regulatory target of p53. In osteosarcoma cells, over-expression of this same miRNA construct resulted in apoptosis and G1 cell cycle arrest $[49,50]$. These results highlight the role of individual classes of miRNAs in regulating multiple tumorigenic processes in a variety of tumors.

Since apoptosis is a complex process that involves interactions between a large number of proteins and indirect regulation by many others, it is likely that there are other miRNAs playing roles in the regulation of these cellular events. miR-221 and miR-222, for example, target the $3^{\prime} \mathrm{UTR}$ of $\mathrm{p} 27^{\mathrm{Kip} 1}$, a tumor suppressor gene that has been demonstrated to promote apoptosis [52-54]. Further study will certainly identify additional miRNAs critical to the ability of cancer cells to escape apoptosis.

\section{miRNA regulation of 3p21.3 region tumor suppressor genes}

More than 25 years have passed since the first identification and characterization of deletions in the short arm of chromosome 3 (3p) in small cell lung cancer cell lines and cultures [55]. More recent evidence demonstrates that loss of expression in the 3 p region occur in up to $90 \%$ to $100 \%$ of lung tumors, and may play a critical role in the initiation of lung tumorigenesis [56]. Although the functions of the genes located in this region have not been fully elucidated, several act as tumor suppressors by causing the disregulation of critical intracellular processes 
such as apoptosis [57,58]. It has been proposed that hemizygous deletion of tumor suppressor genes in the $3 p$ region could be coupled with other regulatory interactions that result in further down regulation of gene expression thereby inducing clonal outgrowth and tumor initiation [56]. Evidence is emerging that tumor suppressors in this region are likely to be regulated by miRNA activity. FUS1/TUSC 2 is a tumor suppressor gene located on 3p21.3 that has been shown to be negatively regulated by the activities of miR-197, miR-93, miR-98 and miR-378 [9,59]. Reduced or complete loss of Fus1 expression was found in $82 \%$ and $100 \%$ of non-small cell and small cell lung cancer cell lines [60], and elevated levels of miR-93 and miR-197 have been shown to correlate with reduced Fus1 expression in NSCLC tumor specimens [59]. This and other evidence suggests thatlow Fus1 levels are the result of post-transcriptional miRNAmediated negative regulation [57,61], which could be enhanced in a haploinsufficient Fus1 background. Although miRNA expression and function in the context of $3 \mathrm{p} 21$ deletions needs further investigation, evidence suggests that miRNA regulation of the remaining alleles of $3 \mathrm{p} 21$ tumor suppressor genes is important to the initiation and progression of lung cancer.

\section{miRNA Regulation of Angiogenesis}

The formation of new vasculature is crucial for tumor development. Solid tumors greater than 1-2 $\mathrm{mm}^{3}$ need to recruit new blood vessels to remove metabolic waste and provide oxygen and nutrients, a critical process that allows small developing neoplasias to enter a state of uncontrolled proliferation. Access to new vascularization also provides the tumor with new routes for dissemination, and current thought is that the degree of vascularization of a solid tumor is a direct indicator of its metastatic potential. Prior to the formation of neovasculature, a developing solid tumor is generally in an oxygen-starved or hypoxic state, triggering the release of a variety of angiogenic molecules and growth factors that recruit new blood vessels to the tumor site by promoting local basement membrane degradation, endothelial cell invasion, migration, and proliferation, resulting in the formation of capillary tubes [62,63]. Pathways controlling these complex processes have been the focus of efforts to use novel therapeutics to inhibit this process and starve developing tumors of oxygen and nutrients. For example, the vascular endothelial growth factor (VEGF) is an important mediator of angiogenesis during tumor development, and this molecule and its receptor (VEGFR) have been primary targets of therapies designed to target pathological angiogenic signaling [64].

Although their specific roles in lung cancer angiogenesis are poorly characterized to date, many of the previously described miRNAs have been found to be important regulators of angiogenesis in other contexts. Preliminary work by Yang et al. showed that mice who were homozygous for a deletion in the miRNA processing gene Dicer were not viable and died within 14.5 days of gestation due to a lack of angiogenesis [65]. Other studies have confirmed an important role for Dicer-mediated miRNA processing in the angiogenic response in vitro and in vivo, both during normal physiological processes and in the context of cancer models [66-71]. miR-126 is highly expressed during embryonic development and in endothelial cells [72], implicating this miRNA in promoting angiogenic processes. In vivo evidence also shows that miR-126 is involved the regulation of endothelial responses to angiogenic growth factors such as VEGF, and that targeted deletion of this miRNA results in defective vascularization and embryonic death in both mice and zebrafish [72-74]. Liu, et al. investigated the involvement of miR-126 in the regulation of angiogenic processes in a lung cancer model [75]. They found decreased expression of miR-126 and increased expression of VEGF-A in various lung cancer cell lines, and showed that introduction of miR-126 using a lentiviral vector could down-regulate the expression of VEGF-A and inhibit growth. They also observed significant reductions in average tumor weight in mice inoculated with miR-126 infected tumor cells compared to control mice inoculated with tumor cells infected with control vector ( $\mathrm{p}<$ 0.001). Other miRNAs have been found to control angiogenic processes by directly regulating angiogenic factor production [76]. For example, several miRNAs have been predicted to target 
VEGF through both competitive (miR-93, miR-125a, miR-302d, miR-373, and miR-378) and coordinated (miR-15b, miR-16, miR-20a, and miR-20b) interactions, and transfection of miR-20a and miR-20b has been shown to regulate the expression of VEGF and other angiogenic factors in human carcinoma cells in vitro [77].

Other factors involved in angiogenesis have been implicated as targets of miRNA regulation. These include the miR-17-92 cluster (miR-17, miR-18a, miR-19a, miR-20a, miR-19b-1 and miR-92a-1) which down-regulates anti-angiogenic proteins such as thrombospondin-1 (Tsp1) and connective tissue growth factor (CTGF) [78], and has been shown to induce tumor vascularization when over-expressed in a mouse model of colon cancer. miRNAs that restrict angiogenesis by inhibiting endothelial cell migration and proliferation include miR-221 and miR-222, which target the stem cell factor receptor c-kit, a ligand involved in stem cell factor (SCF)-mediated angiogenesis [79]. Several other miRNAs have been found to be positive regulators of angiogenesis have been identified in vitro, including miR-27b, miR-130a, and let-7 $[68,80,81]$.

Identification of these miRNAs as important regulators of angiogenesis is providing a greater understanding of the complex pathways involved in tumor growth. Further work is needed to characterize their roles in regulating neo-angiogenic processes in clinical settings, which should also provide more opportunities for therapeutic intervention through reducing the ability of cancer cells to modify their microenvironments to promote survival and proliferation.

\section{miRNA Regulation of Metastasis and Invasion}

Invasion of a primary tumor into surrounding tissues followed by dissemination and growth of secondary malignancies (metastasis) requires a concerted series of events including dissociation of primary tumor cells from the primary neoplasia, entry into the circulatory system, and colonization at distant sites. Failure of any of these steps precludes metastasis, making the spread of cancer to distal sites a highly inefficient process. It has been estimated that fewer than 1 in 10,000 of disseminated cancer cells develop distant macroscopic malignancies [82]. Nevertheless, metastasis is a common event in cancer pathology and represents the primary cause of cancer related mortality. The series of steps needed for metastatic spread involves changes in the expression of many genes; investigations of miRNA regulation of these steps have identified several miRNAs that either promote or inhibit metastatic potential.

A process central to the study of cancer metastasis is the epithelial to mesenchymal transition (EMT). Although extensive during embryonic development, this cellular event is rare in normal adult human cells, occurring predominantly during wound healing and kidney fibrosis [83, 84]. EMT is characterized by the loss of E-cadherin-mediated cell adhesion and an increase in cell motility, and cancer cells often initiate this cellular event to promote invasion and metastasis. Conversion to the mesenchymal state is proposed to allow cancer cells to break free from the primary tumor, invade the basement membrane for entry into the circulation, and colonize to distant sites. EMT is also a reversible process, and cancer cells will revert back to a proliferative epithelial phenotype following colonization at a distant metastatic site [85]. The important role of miRNAs in positively regulating metastatic potential and the EMT was first highlighted by the discovery that the ectopic expression of miR-10b could promote tumor invasion and metastasis in normally non-aggressive breast cancer cells [86]. Forced expression of this miRNA in non-metastatic xenografts using two different cell lines had no effect on the growth rates of these cells, but significantly increased invasive potential and the appearance of lung metastases. miR-10b inhibits the expression of HOXD10, a transcriptional repressor that acts to reduce the expression of a variety of factors involved in cell invasion and migration $[87,88]$. miR-10b was also shown to be the most significantly up-regulated miRNA in 
glioblastoma multiforme (GBM) compared to normal tissues by microarray analysis [89], and was also shown to be over-expressed in pancreatic adenocarcinoma, one of the most aggressive tumors with respect to early metastatic potential and poor survival [90]. Several other miRNAs have been found to positively regulate metastatic potential of cancer cells. For example, overexpression of miR-21 has been associated with both liver metastasis and high levels of expression of the proliferation marker Ki-67 in pancreatic tumors [91]. Transfection of a panel of miRNAs in a non-metastatic breast cancer cell line (MCF-7) revealed two miRNAs (miR-373 and miR-520c) that induced a migratory and invasive phenotype with no effect on cell proliferation in vitro, and tail vein injection of luciferase-tagged MCF-7 cells expressing either of the two miRNAs in SCID mice showed high levels of lung or osteolytic metastases compared to injection of control cells or cells expressing a mutant form of miR-373 [92]. These effects were explained by miRNA-mediated suppression of CD44, a cell surface glycoprotein involved in cell-cell interactions, cell adhesion, and migration [93].

miRNAs are also involved in negatively regulating EMT and tumor metastasis. The miR-200 family of miRNAs has recently been identified as a potent regulator of EMT [94]. Members of this family have been shown to cooperatively regulate the E-cadherin transcriptional repressors ZEB1 and ZEB2 [94-97], with ectopic expression of miR-200 family members increasing E-cadherin expression and reducing the motility of cancer cells. Conversely, reducing miR-200 levels induced EMT in a cancer cell line that expressed high levels of these miRNAs [94]. In another study, invasive breast cancer cells with a mesenchymal phenotype or breast cancer specimens that lacked E-cadherin expression were notably devoid of miR-200 expression [95], suggesting clinical significance of miR-200 regulation of tumor metastasis. Studies in mouse models of lung adenocarcinoma have further investigated the involvement of the miR-200 family in lung cancer metastasis. miRNA profiling of metastasis-prone, metastasis-intermediate, and metastasis-incompetent cell lines revealed only a small number of differentially expressed miRNAs, with the metastasis-prone cells showing lower expression levels of all miR-200 family members compared to the other two cell lines [98]. In this study, constitutive expression of the miR-200b cluster (miR-200b, miR-200a and miR-429) in metastasis-prone cells imparted a reduced invasive and migratory phenotype with a more epithelial baseline phenotype in vitro. miR-200 expression also reverted the metastasis-prone cells to a phenotype that resembled the metastasis-incompetent cells at a transcriptional level. Additionally, no metastases formed in mice that developed primary tumors following subcutaneous injection of miR-200 transfected cells, compared to a $100 \%$ rate of metastasis in tumor-bearing mice following injection with untransfected metastasis-prone cells. These results support an important role for the miR-200 family in regulating the EMT and restricting the metastatic potential of lung tumor cells.

Additional miRNAs have been identified as negative regulators of cellular metastatic potential. A recent study used microarray-based profiling to evaluate miRNA expression in breast cancer cells previously identified to have high metastatic potential [99]. Several miRNAs had highly reduced expression in metastatic sub-lines compared to the parental cells, and forced expression of three - miR-335, miR-206, and miR-126 — using a retroviral-based expression system reduced the ability of otherwise metastatic-prone cells to metastasize to lung or bone. Analysis of archived primary breast cancer tissue also showed that patients with low expression of miR-335, miR-206 or miR-126 had a shorter time to metastatic relapse. Low levels of miR-335 or miR-126 were associated with poor overall metastasis-free survival relative to patients whose tumors expressed high levels of these miRNAs. An investigation of miR-126 in the regulation of invasive potential in lung cancer revealed an inverse relationship between Crk and miR-126 expression in squamous cell tumors [100]. Forced over-expression of miR-126 reduced the expression of Crk protein, which is a mediator of signaling pathways important for a variety of cellular processes including motility and adhesion and reduced expression of which leads to cancer cell invasion [101,102]. 
Overall, results from these studies highlight the importance of miRNAs in regulating invasive and metastatic processes, and the potential utility of microRNA levels as a means of predicting therapeutic outcome. Although the roles of some of the miRNAs discussed above have not been investigated in lung cancers, the above studies indicate that these miRNAs target genes that are associated with general metastasis processes, suggesting that their involvement in lung tumor metastasis and invasion is worth investigation.

\section{The multiple functional properties of miRNAs}

Since miRNAs commonly have multiple target genes, a single miRNA can affect multiple cellular processes in tumorigenesis. As summarized in Table 1, several miRNAs have been shown to target multiple cancer-related genes and processes. For example, in addition to targeting PTEN, miR-21 also targets PDCD4, a pro-apoptotic gene that inhibits tumorigenesis and whose down-regulation has been linked to poor survival in colon and lung cancer patients [103-105], and the AP-1 transcription factor, a heterodimer made up of members of the c-Fos, c-Jun, ATF and JDP families, which regulates a number of cellular processes including differentiation, proliferation, and apoptosis [106]. The let-7 family has been shown to inhibit the expression of several oncogenes including RAS, MYC and HMGA2 [32-34,107]. Interestingly, it has recently been observed that tumors with down-regulation of these miRNAs show a concomitant increase in miR-21 expression [108]. It is therefore suggested that the oncogenic miR-21 could be an indirect downstream target of the let-7 family. Several studies have implicated the miR-17-92 cluster of miRNAs as an actual oncogene with important regulatory effects on pathologic tumor cell proliferation in various tissues including breast and lung [109-111]. This cluster has been shown to inhibit lymphocytic PTEN expression leading to increased cancer cell proliferation in mice [112]. Members of this miRNA family also control expression of the E2F family of transcription factors in an autoregulatory feedback loop [10, 113]. miR-15/16 target G1 cyclins in an Rb-dependent manner [114-117], suggesting that this cluster could be involved in controlling different tumorigenic processes in various types of cancer. miR-29 down-regulation of Mcl-1, coupled with the previously described role of miR-29 in epigenetic DNA methylation, means that enhanced expression could also affect more than one process during tumorigenesis $[16,45,46]$. Two other miRNAs, miR-221 and miR-222, target the 3'UTR of both Kit and the p27 ${ }^{\text {Kip1 }}$ tumor suppressor [52-54] and are associated with resistance to TRAIL-induced apoptosis [118]. The miR-34 family has been demonstrated to target three genes that are involved in tumorigenesis: CDK4/6, cyclinE2 and E2F3 [49,50].

Overall, the above studies support multiple roles for individual miRNAs in regulating tumorigenic processes in a variety of tumors. These varied roles of a single miRNA highlight the overall complexity of miRNA-based regulation. In the context of miRNAs as therapeutic targets, the fact that one miRNA targets multiple genes could be beneficial, if the multiple targets of an individual miRNA function in the same direction with respect to promoting cancer cell proliferation, which appears to be truein most cases based on current data. On the other hand, it could also create a significant side effects if the multiple target genes function in opposite directions. The thorough dissection of the myriad interactions within and between miRNAs and their targets will therefore be required for the development of effective therapeutic approaches.

\section{The disregulation of miRNA expression in cancer development}

Emerging evidence shows that deregulation of miRNAs might be a primary driver of cancer initiation and progression, meaning that a greater understanding of the regulatory mechanisms of miRNA expression could lead to novel strategies for the prevention and treatment of cancers. Several studies have investigated the mechanisms regulating the expression of several miRNAs 
that play important roles in tumorigenesis. For example, as an anti-apoptotic miRNA, miR-21 has been shown to be up-regulated in various cancer types including lung cancers $[119,120]$. Seike, et al demonstrated that increased EGFR signaling due to a positive EGFR mutational status could enhance expression of miR-21 [48], suggesting that miR-21 is regulatory target of EGFR. Recent work has shown that miR-21 acts as both a target and regulator of the AP-1 transcription factor [106], demonstrating a novel type of auto-regulatory loop that highlights the potential complexity of miRNA-mediated regulation of oncogenic processes involved in cancer cell proliferation. Another study investigated the expression of miR-10b, which is highly expressed in metastatic breast cancer cells and positively regulates cell migration and invasion, and showed that it is directly regulated by Twist, a transcription factor critically involved in EMT [86].

The miR-34 family of miRNAs is under-expressed in a variety of tumors. miRNA profiling shows that the expression of miR-34a, miR-34b and miR-34c are directly correlated with expression of the p53 tumor suppressor [51], and these miRNAs are induced in a p53-dependent manner by oncogenic stress and DNA damage. Ectopic expression of miR-34a, miR-34b, and miR-34c induces cell cycle arrest in tumor cell lines [51]. These data suggest that the p53dependent expression of miR-34 and the subsequent effects on the translation of downstream targets could be a primary mechanism by which p 53 induces cell growth arrest and apoptosis. The miR-17-92 cluster of miRNAs is often over-expressed in lung cancer and B-cell lymphomas, has been found to promote tumor cell proliferation in these tumors [109,110]. Members of this miRNA family can be induced by c-Myc and its expression is also regulated in an autoregulatory feedback loop via increased expression of the E2F family transcription factors $[10,113]$.

The above data not only indicate that the deregulation of miRNAs may play a primary role in cancer development, but also suggest that many well-studied cancer-related genes, such as EGFR and p53, control expression of oncogenic or tumor suppressor miRNAs. The interactions of these regulatory elements during tumorigenesis adds another level of complexity to the process of cancer cell transformation, eludication of which will be important for the future of the field.

\section{Clinical applications of miRNAs in lung cancer diagnosis and therapy}

MicroRNAs represent a novel paradigm in gene regulation and homeostatic control, and research continues to identify new roles for these regulatory elements in the development and progression of cancer. As these molecules are further characterized, new clinical applications will be developed that will provide oncologists with diagnostic and prognostic tools for stratifying patients based on risk and projected outcome. The identification of specific miRNA profiles could predict response to particular drugs or drug classes, and the variable presence of miRNAs during the course of therapy could also be used for monitoring therapeutic response and assessing the degree of residual disease. Further characterization of the highly complex miRNA regulatory networks will also lead to the identification of many new therapeutic targets and agents by which we may be able to repair the disregulated processes that define the hallmarks of malignant growth.

\section{Prognostic and diagnostic applications}

The central involvement of miRNAs in the development and progression of cancer suggests that these regulatory elements could be particularly useful for extracting diagnostic and/or prognostic information. Current data indicate that every tumor type analyzed by miRNA profiling shows differential expression of miRNAs compared to normal tissues [121], and that particular miRNA signatures are associated with overall prognosis. A expression profile signature of nine miRNAs including miR-23a, miR23b, miR-24-2, miR-29c, miR-146,, 
miR-155, miR-181a, miR-221 and miR-222 was shown to correlate with time to disease progression in patients with chronic lymphocytic leukemia (CLL) [45], and the expression of miR-196a-2 and miR-21 have been significantly associated with survival in patients with pancreatic or colon cancer, respectively [90,122]. A study in lung cancer showed that high mir-155 and low let-7a-2 expression correlated with poor survival [16]. An independent study of 143 cases of resected lung tumors also showed significantly shorter survival in patients with reduced let-7 expression, regardless of disease stage $(p=0.0003)$ [123]. Several other miRNAs have also been shown to have possible diagnostic or prognostic value. These include the protective (let-7, miR-221) and high-risk (miR-137, miR-372, and miR-182) miRNAs, which have been shown to predict the likelihood of survival in lung cancer patients [124], and the miR-17-92 cluster, which is greatly increased in expression in lung cancer [109]. Results from these studies suggests that most protective miRNAs are usually down-regulated in lung cancer while those associated with high risk are generally up-regulated [125], and that differential expression of miRNAs could have diagnostic significance and prognostic value.

miRNAs have also been shown to be predictive of response to cancer therapy. As previously described, miR-128b was found to regulate EGFR in NSCLC cell lines, and loss of heterozygosity of miR-128b was shown to significantly correlate with response to EGFRtargeted therapy. Altered expression of let-7 was observed in response to radiotherapy, with forced over-expression of let-7 in lung cancer cells found to sensitize them to radiotherapy in vitro and to increase radiation-induced cell death in an in vivo C. elegans model [126]. Additional examples where miRNA status was found to predict response to therapy have emerged in other tumor types. For example, patients with hepatocellular carcinoma had better response to interferon-alpha therapy when the tumor expression level of miR-26 was low [127].

Further research into the complex regulatory networks modulated by miRNAs will identify additional miRNAs that predict response to existing therapies, providing clinicians with additional tools for stratifying patients and optimizing individualized therapy regimens.

The utility of circulating miRNAs for cancer diagnosis is also being investigated, highlighting their potential as non-invasive diagnostic tools for cancer detection. Plasma levels of both miR-92 and miR-17-3p were found to be significantly elevated in patients with colorectal cancer (CRC) compared to controls ( $\mathrm{p}<0.0005)$, and these levels were significantly reduced in $\mathrm{CRC}$ patients following resection of the tumors $(\mathrm{p}<0.05)$ [128]. In another study, specific serum miRNA expression profiles have also been identified in patients with lung and colon cancers, and two of the miRNAs, miR-25 and miR-223, were further validated in an independent trial of 75 healthy donors and 152 NSCLC patients, suggesting these two miRNAs have potential to serve as diagnostic marker for NSCLCs [19]. Other miRNAs such as miR-141 and miR-21 have been reported to be predictive for the presence of prostate cancer or to act as a biomarker for the diagnosis of B-cell lymphoma, respectively [18,129]. The presence of solid malignancies is typically confirmed by biopsy, an approach that is ineffective for evaluating the existence or extent of metastatic spread. The development of non-invasive protocols for diagnosing tumors is therefore of substantial clinical interest, and the measurement of circulating miRNAs could be a promising approach for the timely detection and diagnosis of both primary and metastatic malignancies. Variability in lung cancer histology and prognosis means that better methods are needed for classifying lung tumors and stratifying patients for traditional cytotoxic therapies. In addition, the advent of targeted therapies means that molecular classification of particular lung cancer subtypes can further direct the individualization of therapeutic modalities and improve patient outcomes. miRNAs have emerged as a potentially effective method for classifying specific tissues, and preliminary studies indicated that miRNA profiles could distinguish squamous and non-squamous lung cancer histologies [16]. More recently, Lebanony and colleagues found that expression of a 
miR-205 was a highly specific biomarker for squamous cell lung carcinoma [130]. Following microarray miRNA profiling and further characterization of miRNA expression levels, miR-205 was shown to distinguish squamous cell carcinoma from adenocarcinoma subtypes with a high degree of specificity (90\%) and sensitivity (96\%). From these data, the authors developed and validated a diagnostic protocol, providing a potentially effective and convenient assay for classifying lung cancer histological subtypes. Other studies have also identified miRNA profiles that potentially distinguish between adenocarcinoma and squamous cell tumors [131]. These methods could prove to be invaluable by providing clinicians with additional tools to individualize therapy.

MicroRNAs also have potential for diagnosing the origin of metastases based on differential expression of these regulatory elements relative to normal tissue. Metastatic tumors of unknown origin account for up to 5\% of cancers [132]; these cases represent a substantial clinical dilemma due to the difficulty of early detection and the lack of data for appropriate clinical management. Systematic miRNA expression analysis has been shown to outperform messenger RNA profiling for distinguishing and diagnosing poorly differentiated tumors [133], with several studies reporting that overall miRNA expression levels are lower in tumors than in normal tissue. miRNA expression may therefore be related to the degree of differentiation, a possibility that has been supported by other profiling studies. These data suggest that miRNAs could be an effective tool for identifying the presence and origin of small malignant growths against the background of normal physiological activity.

Mutational status of oncogenic miRNAs and regulatory regions in known oncogenes represent another strategy by which to identify high-risk patients. Germline mutations in miRNAs have been identified that confer a higher predisposition for developing cancer. MicroRNA mutations were identified in approximately $10 \%$ of patients with CLL [134], and a germline G to A mutation in let-7e was recently found in a patient with prostate cancer that further investigation showed caused reduced expression of this miRNA in vivo [135]. Common genetic variations including single nucleotide polymorphisms in either miRNAs or miRNA complementary sites in the 3'UTRs of oncogenes have also been identified that can confer risk for developing malignancies in the lung, breast, or thyroid (reviewed in [134]).

The above studies demonstrated that miRNA profiling have enormous potential as diagnostic and prognostic marker for cancer and have several significant advantages over traditional approaches.

\section{Targeting miRNAs for therapeutic benefit}

microRNA regulation of multiple cancer-related pathways provides numerous opportunities for therapeutic intervention. Competitive inhibition of miRNAs or the delivery of exogenously produced miRNAs could provide substantial therapeutic benefit by reducing the activity of pro-oncogenic miRNAs or enriching cells with anti-oncogenic miRNAs, respectively. These approaches are still in the preclinical stages, although intriguing evidence is emerging that supports their use in clinical applications. Mimics of miRNAs including miR-15a, miR-16-1, and miR-29 have been introduced into mouse models, showing that these approaches can suppress the growth of leukemic cells [136], and expression of miR-29 family members has been shown to reduce tumorigenic potential in a lung cancer model [39]. Exogenous delivery of a synthetic let-7 mimic has been used to induce mediate remission of established NSCLC tumors in mice [32].

Unlike miRNA mimics, miRNA inhibitors are not processed by the miRNA biogenesis pathway. Such inhibitors are chemically modified single-stranded oligonucleotides complementary to mature miRNAs. The chemical modifications, including phosphorothioate, 2'-O-methyl, and locked nucleic acid (LNA) substitutions increase their resistance to 
degradation by nucleases. The inhibitors are designed to bind to the mature miRNA within the RISC complex and act as competitive inhibitors, but can also bind pri-miRNA or pre-miRNA and abrogate their processing, export from the nucleus or incorporation into the RISC complex. Treatment with a miRNA inhibitor (antagomir) [137] of oncogenic miR-17-5p resulted in complete tumor regression in 30\% of mice [138]. Results from other studies in mice and primates showed effective silencing of miR-122 using inhibitors with locked nucleic acid (LNA) substitutions and cholesterol conjugation with no evidence of treatment-related toxicity [139], supporting the development of these approaches in the clinical setting.

Overall, miRNA-based therapeutics have enormous, but as yet, unrealized potential. Adenoassociated virus mediated delivery of miR-26a has been used to downregulate cyclins D2 and E2 and thereby ameliorate hepatocellular carcinoma in mice [140], suggesting an alternative to delivery of either single-or double-stranded miRNA mimics. Future work will focus on both chemical modifications and delivery vehicles in order to maximize the therapeutic benefits and minimize the side effects of strategies designed to alter intra-cellular levels of specific miRNAs.

\section{Conclusions}

The study of microRNA biology is maturing - the questions that are being asked have moved from whether miRNA are differentially expressed in cancers to whether miRNAs are of therapeutic utility. Profiling human tumors has identified signatures associated with risk, diagnosis, prognosis and therapeutic response. Differential expression of highly conserved non-coding genes in malignant cells relative to normal cells is providing better understanding of disease progression. Correlation between genomic locations of miRNAs and cancerassociated genomic regions has coupled aberrant miRNA expression to the genetic basis of cancer. The expanded study of pathways relevant to cancer processes is leading to new insights on the cellular and epigenetic regulation of miRNA genes and miRNA pathway components. The field is moving in the direction of systems biology which will take us from investigations of single miRNAs and one or a few major targets to more comprehensive explorations of the regulatory networks through which they interact and function, and will integrate microRNAs into the already complex signaling, metabolic, protein interaction and gene regulatory networks.

\section{Acknowledgments}

The authors gratefully acknowledge the technical assistance of Paul Card and thank Robert Borkowski for thoughtful insights and discussions and critical reading of the manuscript. This work was supported in part by Public Health Service grant number P50 CA70907 from the UT Southwestern/MD Anderson Cancer Center Lung Specialized Program of Research Excellence (UTSW/MDACC Lung SPORE) and the National Cancer Institute and grant number R01 CA129632 from the National Institutes of Health and the National Cancer Institute.

\section{References}

1. Yekta S, Shih IH, Bartel DP. MicroRNA-directed cleavage of HOXB8 mRNA. Science 2004;304:594596. [PubMed: 15105502]

2. Vasudevan S, Tong Y, Steitz JA. Switching from repression to activation: microRNAs can up-regulate translation. Science 2007;318:1931-1934. [PubMed: 18048652]

3. Novotny GW, Sonne SB, Nielsen JE, Jonstrup SP, Hansen MA, Skakkebaek NE, Rajpert-De Meyts E, Kjems J, Leffers $\mathrm{H}$. Translational repression of E2F1 mRNA in carcinoma in situ and normal testis correlates with expression of the miR-17-92 cluster. Cell Death Differ 2007;14:879-882. [PubMed: 17218954]

4. He L, He X, Lowe SW, Hannon GJ. microRNAs join the p53 network-another piece in the tumoursuppression puzzle. Nat Rev Cancer 2007;7:819-822. [PubMed: 17914404] 
5. Cho WC. OncomiRs: the discovery and progress of microRNAs in cancers. Mol Cancer 2007;6:60. [PubMed: 17894887]

6. Hwang HW, Mendell JT. MicroRNAs in cell proliferation, cell death, and tumorigenesis. Br J Cancer 2006;94:776-780. [PubMed: 16495913]

7. Esquela-Kerscher A, Slack FJ. Oncomirs - microRNAs with a role in cancer. Nat Rev Cancer 2006;6:259-269. [PubMed: 16557279]

8. Hebert C, Norris K, Scheper MA, Nikitakis N, Sauk JJ. High mobility group A2 is a target for miRNA-98 in head and neck squamous cell carcinoma. Mol Cancer 2007;6:5. [PubMed: 17222355]

9. Lee DY, Deng Z, Wang CH, Yang BB. MicroRNA-378 promotes cell survival, tumor growth, and angiogenesis by targeting SuFu and Fus-1 expression. Proc Natl Acad Sci U S A 2007;104:2035020355. [PubMed: 18077375]

10. O’Donnell KA, Wentzel EA, Zeller KI, Dang CV, Mendell JT. c-Myc-regulated microRNAs modulate E2F1 expression. Nature 2005;435:839-843. [PubMed: 15944709]

11. Mercatelli N, Coppola V, Bonci D, Miele F, Costantini A, Guadagnoli M, Bonanno E, Muto G, Frajese GV, De Maria R, Spagnoli LG, Farace MG, Ciafre SA. The inhibition of the highly expressed miR-221 and miR-222 impairs the growth of prostate carcinoma xenografts in mice. PLoS ONE 2008;3:e4029. [PubMed: 19107213]

12. Felicetti F, Errico MC, Bottero L, Segnalini P, Stoppacciaro A, Biffoni M, Felli N, Mattia G, Petrini M, Colombo MP, Peschle C, Care A. The promyelocytic leukemia zinc finger-microRNA-221/-222 pathway controls melanoma progression through multiple oncogenic mechanisms. Cancer Res 2008;68:2745-2754. [PubMed: 18417445]

13. Wickramasinghe NS, Manavalan TT, Dougherty SM, Riggs KA, Li Y, Klinge CM. Estradiol downregulates miR-21 expression and increases miR-21 target gene expression in MCF-7 breast cancer cells. Nucleic Acids Res 2009;37:2584-2595. [PubMed: 19264808]

14. Yang Y, Chaerkady R, Beer MA, Mendell JT, Pandey A. Identification of miR-21 targets in breast cancer cells using a quantitative proteomic approach. Proteomics 2009;9:1374-1384. [PubMed: 19253296]

15. Si ML, Zhu S, Wu H, Lu Z, Wu F, Mo YY. miR-21-mediated tumor growth. Oncogene 2007;26:2799_ 2803. [PubMed: 17072344]

16. Yanaihara N, Caplen N, Bowman E, Seike M, Kumamoto K, Yi M, Stephens RM, Okamoto A, Yokota J, Tanaka T, Calin GA, Liu CG, Croce CM, Harris CC. Unique microRNA molecular profiles in lung cancer diagnosis and prognosis. Cancer Cell 2006;9:189-198. [PubMed: 16530703]

17. Taylor DD, Gercel-Taylor C. MicroRNA signatures of tumor-derived exosomes as diagnostic biomarkers of ovarian cancer. Gynecol Oncol 2008;110:13-21. [PubMed: 18589210]

18. Mitchell PS, Parkin RK, Kroh EM, Fritz BR, Wyman SK, Pogosova-Agadjanyan EL, Peterson A, Noteboom J, O'Briant KC, Allen A, Lin DW, Urban N, Drescher CW, Knudsen BS, Stirewalt DL, Gentleman R, Vessella RL, Nelson PS, Martin DB, Tewari M. Circulating microRNAs as stable blood-based markers for cancer detection. Proc Natl Acad Sci U S A 2008;105:10513-10518. [PubMed: 18663219]

19. Chen X, Ba Y, Ma L, Cai X, Yin Y, Wang K, Guo J, Zhang Y, Chen J, Guo X, Li Q, Li X, Wang W, Wang J, Jiang X, Xiang Y, Xu C, Zheng P, Zhang J, Li R, Zhang H, Shang X, Gong T, Ning G, Zen $\mathrm{K}$, Zhang CY. Characterization of microRNAs in serum: a novel class of biomarkers for diagnosis of cancer and other diseases. Cell Res 2008;18:997-1006. [PubMed: 18766170]

20. Hanahan D, Weinberg RA. The hallmarks of cancer. Cell 2000;100:57-70. [PubMed: 10647931]

21. Khosravi-Far R, Esposti MD. Death receptor signals to mitochondria. Cancer Biol Ther 2004;3:10511057. [PubMed: 15640619]

22. Holbro T, Beerli RR, Maurer F, Koziczak M, Barbas CF 3rd, Hynes NE. The ErbB2/ErbB3 heterodimer functions as an oncogenic unit: ErbB2 requires ErbB3 to drive breast tumor cell proliferation. Proc Natl Acad Sci U S A 2003;100:8933-8938. [PubMed: 12853564]

23. Scott GK, Goga A, Bhaumik D, Berger CE, Sullivan CS, Benz CC. Coordinate suppression of ERBB2 and ERBB3 by enforced expression of micro-RNA miR-125a or miR-125b. J Biol Chem 2007;282:1479-1486. [PubMed: 17110380]

24. Weiss GJ, Bemis LT, Nakajima E, Sugita M, Birks DK, Robinson WA, Varella-Garcia M, Bunn PA Jr, Haney J, Helfrich BA, Kato H, Hirsch FR, Franklin WA. EGFR regulation by microRNA in lung 
cancer: correlation with clinical response and survival to gefitinib and EGFR expression in cell lines. Ann Oncol 2008;19:1053-1059. [PubMed: 18304967]

25. Webster RJ, Giles KM, Price KJ, Zhang PM, Mattick JS, Leedman PJ. Regulation of epidermal growth factor receptor signaling in human cancer cells by microRNA-7. J Biol Chem 2009;284:5731-5741. [PubMed: 19073608]

26. Eberhart JK, He X, Swartz ME, Yan YL, Song H, Boling TC, Kunerth AK, Walker MB, Kimmel CB, Postlethwait JH. MicroRNA Mirn140 modulates Pdgf signaling during palatogenesis. Nat Genet 2008;40:290-298. [PubMed: 18264099]

27. La Rocca G, Badin M, Shi B, Xu SQ, Deangelis T, Sepp-Lorenzinoi L, Baserga R. Mechanism of growth inhibition by MicroRNA 145: the role of the IGF-I receptor signaling pathway. J Cell Physiol 2009;220:485-491. [PubMed: 19391107]

28. Bos JL. ras oncogenes in human cancer: a review. Cancer Res 1989;49:4682-4689. [PubMed: 2547513]

29. Downward J. Targeting RAS signalling pathways in cancer therapy. Nat Rev Cancer 2003;3:11-22. [PubMed: 12509763]

30. Zajac-Kaye M. Myc oncogene: a key component in cell cycle regulation and its implication for lung cancer. Lung Cancer 2001;34 (Suppl 2):S43-46. [PubMed: 11720740]

31. Johnson SM, Grosshans H, Shingara J, Byrom M, Jarvis R, Cheng A, Labourier E, Reinert KL, Brown D, Slack FJ. RAS is regulated by the let-7 microRNA family. Cell 2005;120:635-647. [PubMed: 15766527]

32. Kumar MS, Erkeland SJ, Pester RE, Chen CY, Ebert MS, Sharp PA, Jacks T. Suppression of nonsmall cell lung tumor development by the let-7 microRNA family. Proc Natl Acad Sci U S A 2008;105:3903-3908. [PubMed: 18308936]

33. Sampson VB, Rong NH, Han J, Yang Q, Aris V, Soteropoulos P, Petrelli NJ, Dunn SP, Krueger LJ. MicroRNA let-7a down-regulates MYC and reverts MYC-induced growth in Burkitt lymphoma cells. Cancer Res 2007;67:9762-9770. [PubMed: 17942906]

34. Mayr C, Hemann MT, Bartel DP. Disrupting the pairing between let-7 and Hmga2 enhances oncogenic transformation. Science 2007;315:1576-1579. [PubMed: 17322030]

35. Muntoni A, Reddel RR. The first molecular details of ALT in human tumor cells. Hum Mol Genet 2005;14(Spec No 2):R191-196. [PubMed: 16244317]

36. Mitomo S, Maesawa C, Ogasawara S, Iwaya T, Shibazaki M, Yashima-Abo A, Kotani K, Oikawa H, Sakurai E, Izutsu N, Kato K, Komatsu H, Ikeda K, Wakabayashi G, Masuda T. Downregulation of miR-138 is associated with overexpression of human telomerase reverse transcriptase protein in human anaplastic thyroid carcinoma cell lines. Cancer Sci 2008;99:280-286. [PubMed: 18201269]

37. Gonzalo S, Jaco I, Fraga MF, Chen T, Li E, Esteller M, Blasco MA. DNA methyltransferases control telomere length and telomere recombination in mammalian cells. Nat Cell Biol 2006;8:416-424. [PubMed: 16565708]

38. Benetti R, Gonzalo S, Jaco I, Munoz P, Gonzalez S, Schoeftner S, Murchison E, Andl T, Chen T, Klatt P, Li E, Serrano M, Millar S, Hannon G, Blasco MA. A mammalian microRNA cluster controls DNA methylation and telomere recombination via Rbl2-dependent regulation of DNA methyltransferases. Nat Struct Mol Biol 2008;15:268-279. [PubMed: 18311151]

39. Fabbri M, Garzon R, Cimmino A, Liu Z, Zanesi N, Callegari E, Liu S, Alder H, Costinean S, Fernandez-Cymering C, Volinia S, Guler G, Morrison CD, Chan KK, Marcucci G, Calin GA, Huebner K, Croce CM. MicroRNA-29 family reverts aberrant methylation in lung cancer by targeting DNA methyltransferases 3A and 3B. Proc Natl Acad Sci U S A 2007;104:15805-15810. [PubMed: 17890317]

40. Hotchkiss RS, Strasser A, McDunn JE, Swanson PE. Cell death. N Engl J Med 2009;361:1570-1583. [PubMed: 19828534]

41. Porkka KP, Pfeiffer MJ, Waltering KK, Vessella RL, Tammela TL, Visakorpi T. MicroRNA expression profiling in prostate cancer. Cancer Res 2007;67:6130-6135. [PubMed: 17616669]

42. Bottoni A, Piccin D, Tagliati F, Luchin A, Zatelli MC, degli Uberti EC. miR-15a and miR-16-1 downregulation in pituitary adenomas. J Cell Physiol 2005;204:280-285. [PubMed: 15648093]

43. Cimmino A, Calin GA, Fabbri M, Iorio MV, Ferracin M, Shimizu M, Wojcik SE, Aqeilan RI, Zupo S, Dono M, Rassenti L, Alder H, Volinia S, Liu CG, Kipps TJ, Negrini M, Croce CM. miR-15 and 
miR-16 induce apoptosis by targeting BCL2. Proc Natl Acad Sci U S A 2005;102:13944-13949. [PubMed: 16166262]

44. Mott JL, Kobayashi S, Bronk SF, Gores GJ. mir-29 regulates Mcl-1 protein expression and apoptosis. Oncogene 2007;26:6133-6140. [PubMed: 17404574]

45. Calin GA, Ferracin M, Cimmino A, Di Leva G, Shimizu M, Wojcik SE, Iorio MV, Visone R, Sever NI, Fabbri M, Iuliano R, Palumbo T, Pichiorri F, Roldo C, Garzon R, Sevignani C, Rassenti L, Alder H, Volinia S, Liu CG, Kipps TJ, Negrini M, Croce CM. A MicroRNA signature associated with prognosis and progression in chronic lymphocytic leukemia. N Engl J Med 2005;353:1793-1801. [PubMed: 16251535]

46. Cummins JM, He Y, Leary RJ, Pagliarini R, Diaz LA Jr, Sjoblom T, Barad O, Bentwich Z, Szafranska AE, Labourier E, Raymond CK, Roberts BS, Juhl H, Kinzler KW, Vogelstein B, Velculescu VE. The colorectal microRNAome. Proc Natl Acad Sci U S A 2006;103:3687-3692. [PubMed: 16505370]

47. Chan JA, Krichevsky AM, Kosik KS. MicroRNA-21 is an antiapoptotic factor in human glioblastoma cells. Cancer Res 2005;65:6029-6033. [PubMed: 16024602]

48. Seike M, Goto A, Okano T, Bowman ED, Schetter AJ, Horikawa I, Mathe EA, Jen J, Yang P, Sugimura H, Gemma A, Kudoh S, Croce CM, Harris CC. MiR-21 is an EGFR-regulated anti-apoptotic factor in lung cancer in never-smokers. Proc Natl Acad Sci U S A 2009;106:12085-12090. [PubMed: 19597153]

49. Tarasov V, Jung P, Verdoodt B, Lodygin D, Epanchintsev A, Menssen A, Meister G, Hermeking H. Differential regulation of microRNAs by 53 revealed by massively parallel sequencing: miR-34a is a p53 target that induces apoptosis and G1-arrest. Cell Cycle 2007;6:1586-1593. [PubMed: 17554199]

50. Hermeking H. The miR-34 family in cancer and apoptosis. Cell Death Differ. 2009

51. He L, He X, Lim LP, de Stanchina E, Xuan Z, Liang Y, Xue W, Zender L, Magnus J, Ridzon D, Jackson AL, Linsley PS, Chen C, Lowe SW, Cleary MA, Hannon GJ. A microRNA component of the p53 tumour suppressor network. Nature 2007;447:1130-1134. [PubMed: 17554337]

52. le Sage C, Nagel R, Egan DA, Schrier M, Mesman E, Mangiola A, Anile C, Maira G, Mercatelli N, Ciafre SA, Farace MG, Agami R. Regulation of the p27(Kip1) tumor suppressor by miR-221 and miR-222 promotes cancer cell proliferation. EMBO J 2007;26:3699-3708. [PubMed: 17627278]

53. Gillies JK, Lorimer IA. Regulation of p27Kip1 by miRNA 221/222 in glioblastoma. Cell Cycle 2007;6:2005-2009. [PubMed: 17721077]

54. Galardi S, Mercatelli N, Giorda E, Massalini S, Frajese GV, Ciafre SA, Farace MG. miR-221 and miR-222 expression affects the proliferation potential of human prostate carcinoma cell lines by targeting p27Kip1. J Biol Chem 2007;282:23716-23724. [PubMed: 17569667]

55. Whang-Peng J, Kao-Shan CS, Lee EC, Bunn PA, Carney DN, Gazdar AF, Minna JD. Specific chromosome defect associated with human small-cell lung cancer; deletion 3p(14-23). Science 1982;215:181-182. [PubMed: 6274023]

56. Zabarovsky ER, Lerman MI, Minna JD. Tumor suppressor genes on chromosome 3p involved in the pathogenesis of lung and other cancers. Oncogene 2002;21:6915-6935. [PubMed: 12362274]

57. Lerman MI, Minna JD. The 630-kb lung cancer homozygous deletion region on human chromosome 3p21.3: identification and evaluation of the resident candidate tumor suppressor genes. The International Lung Cancer Chromosome 3p21.3 Tumor Suppressor Gene Consortium. Cancer Res 2000;60:6116-6133. [PubMed: 11085536]

58. Ji L, Nishizaki M, Gao B, Burbee D, Kondo M, Kamibayashi C, Xu K, Yen N, Atkinson EN, Fang B, Lerman MI, Roth JA, Minna JD. Expression of several genes in the human chromosome 3p21.3 homozygous deletion region by an adenovirus vector results in tumor suppressor activities in vitro and in vivo. Cancer Res 2002;62:2715-2720. [PubMed: 11980673]

59. Du L, Schageman JJ, Subauste MC, Saber B, Hammond SM, Prudkin L, Wistuba Il, Ji L, Roth JA, Minna JD, Pertsemlidis A. miR-93, miR-98, and miR-197 regulate expression of tumor suppressor gene FUS1. Mol Cancer Res 2009;7:1234-1243. [PubMed: 19671678]

60. Prudkin L, Behrens C, Liu DD, Zhou X, Ozburn NC, Bekele BN, Minna JD, Moran C, Roth JA, Ji $\mathrm{L}$, Wistuba Il. Loss and reduction of FUS1 protein expression is a frequent phenomenon in the pathogenesis of lung cancer. Clin Cancer Res 2008;14:41-47. [PubMed: 18172250] 
61. Kondo M, Ji L, Kamibayashi C, Tomizawa Y, Randle D, Sekido Y, Yokota J, Kashuba V, Zabarovsky E, Kuzmin I, Lerman M, Roth J, Minna JD. Overexpression of candidate tumor suppressor gene FUS1 isolated from the $3 \mathrm{p} 21.3$ homozygous deletion region leads to $\mathrm{G} 1$ arrest and growth inhibition of lung cancer cells. Oncogene 2001;20:6258-6262. [PubMed: 11593436]

62. Hanahan D, Folkman J. Patterns and emerging mechanisms of the angiogenic switch during tumorigenesis. Cell 1996;86:353-364. [PubMed: 8756718]

63. Horn L, Sandler AB. Angiogenesis in the treatment of non-small cell lung cancer. Proc Am Thorac Soc 2009;6:206-217. [PubMed: 19349490]

64. Kerbel RS. Tumor angiogenesis. N Engl J Med 2008;358:2039-2049. [PubMed: 18463380]

65. Yang WJ, Yang DD, Na S, Sandusky GE, Zhang Q, Zhao G. Dicer is required for embryonic angiogenesis during mouse development. J Biol Chem 2005;280:9330-9335. [PubMed: 15613470]

66. Bernstein E, Kim SY, Carmell MA, Murchison EP, Alcorn H, Li MZ, Mills AA, Elledge SJ, Anderson KV, Hannon GJ. Dicer is essential for mouse development. Nat Genet 2003;35:215-217. [PubMed: 14528307]

67. Suarez Y, Fernandez-Hernando C, Pober JS, Sessa WC. Dicer dependent microRNAs regulate gene expression and functions in human endothelial cells. Circ Res 2007;100:1164-1173. [PubMed: 17379831]

68. Kuehbacher A, Urbich C, Zeiher AM, Dimmeler S. Role of Dicer and Drosha for endothelial microRNA expression and angiogenesis. Circ Res 2007;101:59-68. [PubMed: 17540974]

69. Suarez Y, Fernandez-Hernando C, Yu J, Gerber SA, Harrison KD, Pober JS, Iruela-Arispe ML, Merkenschlager M, Sessa WC. Dicer-dependent endothelial microRNAs are necessary for postnatal angiogenesis. Proc Natl Acad Sci U S A 2008;105:14082-14087. [PubMed: 18779589]

70. Otsuka M, Zheng M, Hayashi M, Lee JD, Yoshino O, Lin S, Han J. Impaired microRNA processing causes corpus luteum insufficiency and infertility in mice. J Clin Invest 2008;118:1944-1954. [PubMed: 18398510]

71. Shilo S, Roy S, Khanna S, Sen CK. Evidence for the involvement of miRNA in redox regulated angiogenic response of human microvascular endothelial cells. Arterioscler Thromb Vasc Biol 2008;28:471-477. [PubMed: 18258815]

72. Fish JE, Santoro MM, Morton SU, Yu S, Yeh RF, Wythe JD, Ivey KN, Bruneau BG, Stainier DY, Srivastava D. miR-126 regulates angiogenic signaling and vascular integrity. Dev Cell 2008;15:272284. [PubMed: 18694566]

73. Wang S, Aurora AB, Johnson BA, Qi X, McAnally J, Hill JA, Richardson JA, Bassel-Duby R, Olson EN. The endothelial-specific microRNA miR-126 governs vascular integrity and angiogenesis. Dev Cell 2008;15:261-271. [PubMed: 18694565]

74. Kuhnert F, Mancuso MR, Hampton J, Stankunas K, Asano T, Chen CZ, Kuo CJ. Attribution of vascular phenotypes of the murine Egfl7 locus to the microRNA miR-126. Development 2008;135:3989-3993. [PubMed: 18987025]

75. Liu B, Peng XC, Zheng XL, Wang J, Qin YW. MiR-126 restoration down-regulate VEGF and inhibit the growth of lung cancer cell lines in vitro and in vivo. Lung Cancer 2009;66:169-175. [PubMed: 19223090]

76. Fish JE, Srivastava D. MicroRNAs: opening a new vein in angiogenesis research. Sci Signal 2009;2:pe1. [PubMed: 19126861]

77. Hua Z, Lv Q, Ye W, Wong CK, Cai G, Gu D, Ji Y, Zhao C, Wang J, Yang BB, Zhang Y. MiRNAdirected regulation of VEGF and other angiogenic factors under hypoxia. PLoS ONE 2006;1:e116. [PubMed: 17205120]

78. Dews M, Homayouni A, Yu D, Murphy D, Sevignani C, Wentzel E, Furth EE, Lee WM, Enders GH, Mendell JT, Thomas-Tikhonenko A. Augmentation of tumor angiogenesis by a Myc-activated microRNA cluster. Nat Genet 2006;38:1060-1065. [PubMed: 16878133]

79. Poliseno L, Tuccoli A, Mariani L, Evangelista M, Citti L, Woods K, Mercatanti A, Hammond S, Rainaldi G. MicroRNAs modulate the angiogenic properties of HUVECs. Blood 2006;108:30683071. [PubMed: 16849646]

80. Ruan K, Fang X, Ouyang G. MicroRNAs: novel regulators in the hallmarks of human cancer. Cancer Lett 2009;285:116-126. [PubMed: 19464788] 
81. Chen Y, Gorski DH. Regulation of angiogenesis through a microRNA (miR-130a) that downregulates antiangiogenic homeobox genes GAX and HOXA5. Blood 2008;111:1217-1226. [PubMed: 17957028]

82. Hurst DR, Edmonds MD, Welch DR. Metastamir: the field of metastasis-regulatory microRNA is spreading. Cancer Res 2009;69:7495-7498. [PubMed: 19773429]

83. Savagner P, Kusewitt DF, Carver EA, Magnino F, Choi C, Gridley T, Hudson LG. Developmental transcription factor slug is required for effective re-epithelialization by adult keratinocytes. J Cell Physiol 2005;202:858-866. [PubMed: 15389643]

84. Liu Y. Epithelial to mesenchymal transition in renal fibrogenesis: pathologic significance, molecular mechanism, and therapeutic intervention. J Am Soc Nephrol 2004;15:1-12. [PubMed: 14694152]

85. Thiery JP. Epithelial-mesenchymal transitions in tumour progression. Nat Rev Cancer 2002;2:442454. [PubMed: 12189386]

86. Ma L, Teruya-Feldstein J, Weinberg RA. Tumour invasion and metastasis initiated by microRNA-10b in breast cancer. Nature 2007;449:682-688. [PubMed: 17898713]

87. Clark EA, Golub TR, Lander ES, Hynes RO. Genomic analysis of metastasis reveals an essential role for RhoC. Nature 2000;406:532-535. [PubMed: 10952316]

88. Ma L, Weinberg RA. Micromanagers of malignancy: role of microRNAs in regulating metastasis. Trends Genet 2008;24:448-456. [PubMed: 18674843]

89. Ciafre SA, Galardi S, Mangiola A, Ferracin M, Liu CG, Sabatino G, Negrini M, Maira G, Croce CM, Farace MG. Extensive modulation of a set of microRNAs in primary glioblastoma. Biochem Biophys Res Commun 2005;334:1351-1358. [PubMed: 16039986]

90. Bloomston M, Frankel WL, Petrocca F, Volinia S, Alder H, Hagan JP, Liu CG, Bhatt D, Taccioli C, Croce CM. MicroRNA expression patterns to differentiate pancreatic adenocarcinoma from normal pancreas and chronic pancreatitis. JAMA 2007;297:1901-1908. [PubMed: 17473300]

91. Roldo C, Missiaglia E, Hagan JP, Falconi M, Capelli P, Bersani S, Calin GA, Volinia S, Liu CG, Scarpa A, Croce CM. MicroRNA expression abnormalities in pancreatic endocrine and acinar tumors are associated with distinctive pathologic features and clinical behavior. J Clin Oncol 2006;24:46774684. [PubMed: 16966691]

92. Huang Q, Gumireddy K, Schrier M, le Sage C, Nagel R, Nair S, Egan DA, Li A, Huang G, KleinSzanto AJ, Gimotty PA, Katsaros D, Coukos G, Zhang L, Pure E, Agami R. The microRNAs miR-373 and miR-520c promote tumour invasion and metastasis. Nat Cell Biol 2008;10:202-210. [PubMed: 18193036]

93. Goodison S, Urquidi V, Tarin D. CD44 cell adhesion molecules. Mol Pathol 1999;52:189-196. [PubMed: 10694938]

94. Park SM, Gaur AB, Lengyel E, Peter ME. The miR-200 family determines the epithelial phenotype of cancer cells by targeting the E-cadherin repressors ZEB1 and ZEB2. Genes Dev 2008;22:894907. [PubMed: 18381893]

95. Gregory PA, Bert AG, Paterson EL, Barry SC, Tsykin A, Farshid G, Vadas MA, Khew-Goodall Y, Goodall GJ. The miR-200 family and miR-205 regulate epithelial to mesenchymal transition by targeting ZEB1 and SIP1. Nat Cell Biol 2008;10:593-601. [PubMed: 18376396]

96. Burk U, Schubert J, Wellner U, Schmalhofer O, Vincan E, Spaderna S, Brabletz T. A reciprocal repression between ZEB1 and members of the miR-200 family promotes EMT and invasion in cancer cells. EMBO Rep 2008;9:582-589. [PubMed: 18483486]

97. Korpal M, Lee ES, Hu G, Kang Y. The miR-200 family inhibits epithelial-mesenchymal transition and cancer cell migration by direct targeting of E-cadherin transcriptional repressors ZEB1 and ZEB2. J Biol Chem 2008;283:14910-14914. [PubMed: 18411277]

98. Gibbons DL, Lin W, Creighton CJ, Rizvi ZH, Gregory PA, Goodall GJ, Thilaganathan N, Du L, Zhang Y, Pertsemlidis A, Kurie JM. Contextual extracellular cues promote tumor cell EMT and metastasis by regulating miR-200 family expression. Genes Dev 2009;23:2140-2151. [PubMed: 19759262]

99. Tavazoie SF, Alarcon C, Oskarsson T, Padua D, Wang Q, Bos PD, Gerald WL, Massague J. Endogenous human microRNAs that suppress breast cancer metastasis. Nature 2008;451:147-152. [PubMed: 18185580] 
100. Crawford M, Brawner E, Batte K, Yu L, Hunter MG, Otterson GA, Nuovo G, Marsh CB, NanaSinkam SP. MicroRNA-126 inhibits invasion in non-small cell lung carcinoma cell lines. Biochem Biophys Res Commun 2008;373:607-612. [PubMed: 18602365]

101. Feller SM. Crk family adaptors-signalling complex formation and biological roles. Oncogene 2001;20:6348-6371. [PubMed: 11607838]

102. Kobashigawa Y, Sakai M, Naito M, Yokochi M, Kumeta H, Makino Y, Ogura K, Tanaka S, Inagaki F. Structural basis for the transforming activity of human cancer-related signaling adaptor protein CRK. Nat Struct Mol Biol 2007;14:503-510. [PubMed: 17515907]

103. Jansen AP, Camalier CE, Colburn NH. Epidermal expression of the translation inhibitor programmed cell death 4 suppresses tumorigenesis. Cancer Res 2005;65:6034-6041. [PubMed: 16024603]

104. Chen Y, Knosel T, Kristiansen G, Pietas A, Garber ME, Matsuhashi S, Ozaki I, Petersen I. Loss of PDCD4 expression in human lung cancer correlates with tumour progression and prognosis. J Pathol 2003;200:640-646. [PubMed: 12898601]

105. Mudduluru G, Medved F, Grobholz R, Jost C, Gruber A, Leupold JH, Post S, Jansen A, Colburn $\mathrm{NH}$, Allgayer $\mathrm{H}$. Loss of programmed cell death 4 expression marks adenoma-carcinoma transition, correlates inversely with phosphorylated protein kinase B, and is an independent prognostic factor in resected colorectal cancer. Cancer 2007;110:1697-1707. [PubMed: 17849461]

106. Talotta F, Cimmino A, Matarazzo MR, Casalino L, De Vita G, D’Esposito M, Di Lauro R, Verde P. An autoregulatory loop mediated by miR-21 and PDCD4 controls the AP-1 activity in RAS transformation. Oncogene 2009;28:73-84. [PubMed: 18850008]

107. Lee YS, Dutta A. The tumor suppressor microRNA let-7 represses the HMGA2 oncogene. Genes Dev 2007;21:1025-1030. [PubMed: 17437991]

108. Wang Y, Lee CG. MicroRNA and cancer-focus on apoptosis. J Cell Mol Med 2009;13:12-23. [PubMed: 19175697]

109. Hayashita Y, Osada H, Tatematsu Y, Yamada H, Yanagisawa K, Tomida S, Yatabe Y, Kawahara $\mathrm{K}$, Sekido Y, Takahashi T. A polycistronic microRNA cluster, miR-17-92, is overexpressed in human lung cancers and enhances cell proliferation. Cancer Res 2005;65:9628-9632. [PubMed: 16266980]

110. He L, Thomson JM, Hemann MT, Hernando-Monge E, Mu D, Goodson S, Powers S, Cordon-Cardo C, Lowe SW, Hannon GJ, Hammond SM. A microRNA polycistron as a potential human oncogene. Nature 2005;435:828-833. [PubMed: 15944707]

111. Mendell JT. miRiad roles for the miR-17-92 cluster in development and disease. Cell 2008;133:217222. [PubMed: 18423194]

112. Xiao C, Srinivasan L, Calado DP, Patterson HC, Zhang B, Wang J, Henderson JM, Kutok JL, Rajewsky K. Lymphoproliferative disease and autoimmunity in mice with increased miR-17-92 expression in lymphocytes. Nat Immunol 2008;9:405-414. [PubMed: 18327259]

113. Sylvestre Y, De Guire V, Querido E, Mukhopadhyay UK, Bourdeau V, Major F, Ferbeyre G, Chartrand P. An E2F/miR-20a autoregulatory feedback loop. J Biol Chem 2007;282:2135-2143. [PubMed: 17135249]

114. Bandi N, Zbinden S, Gugger M, Arnold M, Kocher V, Hasan L, Kappeler A, Brunner T, Vassella E. miR-15a and miR-16 are implicated in cell cycle regulation in a Rb-dependent manner and are frequently deleted or down-regulated in non-small cell lung cancer. Cancer Res 2009;69:55535559. [PubMed: 19549910]

115. Chen RW, Bemis LT, Amato CM, Myint H, Tran H, Birks DK, Eckhardt SG, Robinson WA. Truncation in CCND1 mRNA alters miR-16-1 regulation in mantle cell lymphoma. Blood 2008;112:822-829. [PubMed: 18483394]

116. Liu Q, Fu H, Sun F, Zhang H, Tie Y, Zhu J, Xing R, Sun Z, Zheng X. miR-16 family induces cell cycle arrest by regulating multiple cell cycle genes. Nucleic Acids Res 2008;36:5391-5404. [PubMed: 18701644]

117. Bonci D, Coppola V, Musumeci M, Addario A, Giuffrida R, Memeo L, D’Urso L, Pagliuca A, Biffoni M, Labbaye C, Bartucci M, Muto G, Peschle C, De Maria R. The miR-15a-miR-16-1 cluster controls prostate cancer by targeting multiple oncogenic activities. Nat Med 2008;14:1271-1277. [PubMed: 18931683] 
118. Garofalo M, Quintavalle C, Di Leva G, Zanca C, Romano G, Taccioli C, Liu CG, Croce CM, Condorelli G. MicroRNA signatures of TRAIL resistance in human non-small cell lung cancer. Oncogene 2008;27:3845-3855. [PubMed: 18246122]

119. Frankel LB, Christoffersen NR, Jacobsen A, Lindow M, Krogh A, Lund AH. Programmed cell death 4 (PDCD4) is an important functional target of the microRNA miR-21 in breast cancer cells. J Biol Chem 2008;283:1026-1033. [PubMed: 17991735]

120. Lu Z, Liu M, Stribinskis V, Klinge CM, Ramos KS, Colburn NH, Li Y. MicroRNA-21 promotes cell transformation by targeting the programmed cell death 4 gene. Oncogene 2008;27:4373-4379. [PubMed: 18372920]

121. Calin GA, Croce CM. MicroRNA signatures in human cancers. Nat Rev Cancer 2006;6:857-866. [PubMed: 17060945]

122. Schetter AJ, Leung SY, Sohn JJ, Zanetti KA, Bowman ED, Yanaihara N, Yuen ST, Chan TL, Kwong DL, Au GK, Liu CG, Calin GA, Croce CM, Harris CC. MicroRNA expression profiles associated with prognosis and therapeutic outcome in colon adenocarcinoma. JAMA 2008;299:425-436. [PubMed: 18230780]

123. Takamizawa J, Konishi H, Yanagisawa K, Tomida S, Osada H, Endoh H, Harano T, Yatabe Y, Nagino M, Nimura Y, Mitsudomi T, Takahashi T. Reduced expression of the let-7 microRNAs in human lung cancers in association with shortened postoperative survival. Cancer Res 2004;64:3753-3756. [PubMed: 15172979]

124. Yu SL, Chen HY, Chang GC, Chen CY, Chen HW, Singh S, Cheng CL, Yu CJ, Lee YC, Chen HS, Su TJ, Chiang CC, Li HN, Hong QS, Su HY, Chen CC, Chen WJ, Liu CC, Chan WK, Li KC, Chen JJ, Yang PC. MicroRNA signature predicts survival and relapse in lung cancer. Cancer Cell 2008;13:48-57. [PubMed: 18167339]

125. Wang QZ, Xu W, Habib N, Xu R. Potential uses of microRNA in lung cancer diagnosis, prognosis, and therapy. Curr Cancer Drug Targets 2009;9:572-594. [PubMed: 19519323]

126. Weidhaas JB, Babar I, Nallur SM, Trang P, Roush S, Boehm M, Gillespie E, Slack FJ. MicroRNAs as potential agents to alter resistance to cytotoxic anticancer therapy. Cancer Res 2007;67:1111111116. [PubMed: 18056433]

127. Ji J, Shi J, Budhu A, Yu Z, Forgues M, Roessler S, Ambs S, Chen Y, Meltzer PS, Croce CM, Qin LX, Man K, Lo CM, Lee J, Ng IO, Fan J, Tang ZY, Sun HC, Wang XW. MicroRNA expression, survival, and response to interferon in liver cancer. N Engl J Med 2009;361:1437-1447. [PubMed: 19812400]

128. Ng EK, Chong WW, Jin H, Lam EK, Shin VY, Yu J, Poon TC, Ng SS, Sung JJ. Differential expression of microRNAs in plasma of patients with colorectal cancer: a potential marker for colorectal cancer screening. Gut 2009;58:1375-1381. [PubMed: 19201770]

129. Lawrie CH, Gal S, Dunlop HM, Pushkaran B, Liggins AP, Pulford K, Banham AH, Pezzella F, Boultwood J, Wainscoat JS, Hatton CS, Harris AL. Detection of elevated levels of tumourassociated microRNAs in serum of patients with diffuse large B-cell lymphoma. Br J Haematol 2008;141:672-675. [PubMed: 18318758]

130. Lebanony D, Benjamin H, Gilad S, Ezagouri M, Dov A, Ashkenazi K, Gefen N, Izraeli S, Rechavi G, Pass H, Nonaka D, Li J, Spector Y, Rosenfeld N, Chajut A, Cohen D, Aharonov R, Mansukhani M. Diagnostic assay based on hsa-miR-205 expression distinguishes squamous from nonsquamous non-small-cell lung carcinoma. J Clin Oncol 2009;27:2030-2037. [PubMed: 19273703]

131. Liang Y. An expression meta-analysis of predicted microRNA targets identifies a diagnostic signature for lung cancer. BMC Med Genomics 2008;1:61. [PubMed: 19087325]

132. Pavlidis N, Fizazi K. Cancer of unknown primary (CUP). Crit Rev Oncol Hematol 2005;54:243250. [PubMed: 15890271]

133. Lu J, Getz G, Miska EA, Alvarez-Saavedra E, Lamb J, Peck D, Sweet-Cordero A, Ebert BL, Mak RH, Ferrando AA, Downing JR, Jacks T, Horvitz HR, Golub TR. MicroRNA expression profiles classify human cancers. Nature 2005;435:834-838. [PubMed: 15944708]

134. Negrini M, Nicoloso MS, Calin GA. MicroRNAs and cancer--new paradigms in molecular oncology. Curr Opin Cell Biol 2009;21:470-479. [PubMed: 19411171] 
135. Wu M, Jolicoeur N, Li Z, Zhang L, Fortin Y, L'Abbe D, Yu Z, Shen SH. Genetic variations of microRNAs in human cancer and their effects on the expression of miRNAs. Carcinogenesis 2008;29:1710-1716. [PubMed: 18356149]

136. Calin GA, Cimmino A, Fabbri M, Ferracin M, Wojcik SE, Shimizu M, Taccioli C, Zanesi N, Garzon R, Aqeilan RI, Alder H, Volinia S, Rassenti L, Liu X, Liu CG, Kipps TJ, Negrini M, Croce CM. MiR-15a and miR-16-1 cluster functions in human leukemia. Proc Natl Acad Sci U S A 2008;105:5166-5171. [PubMed: 18362358]

137. Krutzfeldt J, Kuwajima S, Braich R, Rajeev KG, Pena J, Tuschl T, Manoharan M, Stoffel M. Specificity, duplex degradation and subcellular localization of antagomirs. Nucleic Acids Res 2007;35:2885-2892. [PubMed: 17439965]

138. Fontana L, Fiori ME, Albini S, Cifaldi L, Giovinazzi S, Forloni M, Boldrini R, Donfrancesco A, Federici V, Giacomini P, Peschle C, Fruci D. Antagomir-17-5p abolishes the growth of therapyresistant neuroblastoma through p21 and BIM. PLoS ONE 2008;3:e2236. [PubMed: 18493594]

139. Elmen J, Lindow M, Schutz S, Lawrence M, Petri A, Obad S, Lindholm M, Hedtjarn M, Hansen HF, Berger U, Gullans S, Kearney P, Sarnow P, Straarup EM, Kauppinen S. LNA-mediated microRNA silencing in non-human primates. Nature 2008;452:896-899. [PubMed: 18368051]

140. Kota J, Chivukula RR, O’Donnell KA, Wentzel EA, Montgomery CL, Hwang HW, Chang TC, Vivekanandan P, Torbenson M, Clark KR, Mendell JR, Mendell JT. Therapeutic microRNA delivery suppresses tumorigenesis in a murine liver cancer model. Cell 2009;137:1005-1017. [PubMed: 19524505]

141. Zhu S, Si ML, Wu H, Mo YY. MicroRNA-21 targets the tumor suppressor gene tropomyosin 1 (TPM1). J Biol Chem 2007;282:14328-14336. [PubMed: 17363372]

142. Garofalo M, Di Leva G, Romano G, Nuovo G, Suh SS, Ngankeu A, Taccioli C, Pichiorri F, Alder H, Secchiero P, Gasparini P, Gonelli A, Costinean S, Acunzo M, Condorelli G, Croce CM. miR-221\&222 regulate TRAIL resistance and enhance tumorigenicity through PTEN and TIMP3 downregulation. Cancer Cell 2009;16:498-509. [PubMed: 19962668]

143. Sun F, Fu H, Liu Q, Tie Y, Zhu J, Xing R, Sun Z, Zheng X. Downregulation of CCND1 and CDK6 by miR-34a induces cell cycle arrest. FEBS Lett 2008;582:1564-1568. [PubMed: 18406353]

144. Bommer GT, Gerin I, Feng Y, Kaczorowski AJ, Kuick R, Love RE, Zhai Y, Giordano TJ, Qin ZS, Moore BB, MacDougald OA, Cho KR, Fearon ER. p53-mediated activation of miRNA34 candidate tumor-suppressor genes. Curr Biol 2007;17:1298-1307. [PubMed: 17656095]

145. Welch C, Chen Y, Stallings RL. MicroRNA-34a functions as a potential tumor suppressor by inducing apoptosis in neuroblastoma cells. Oncogene 2007;26:5017-5022. [PubMed: 17297439] 

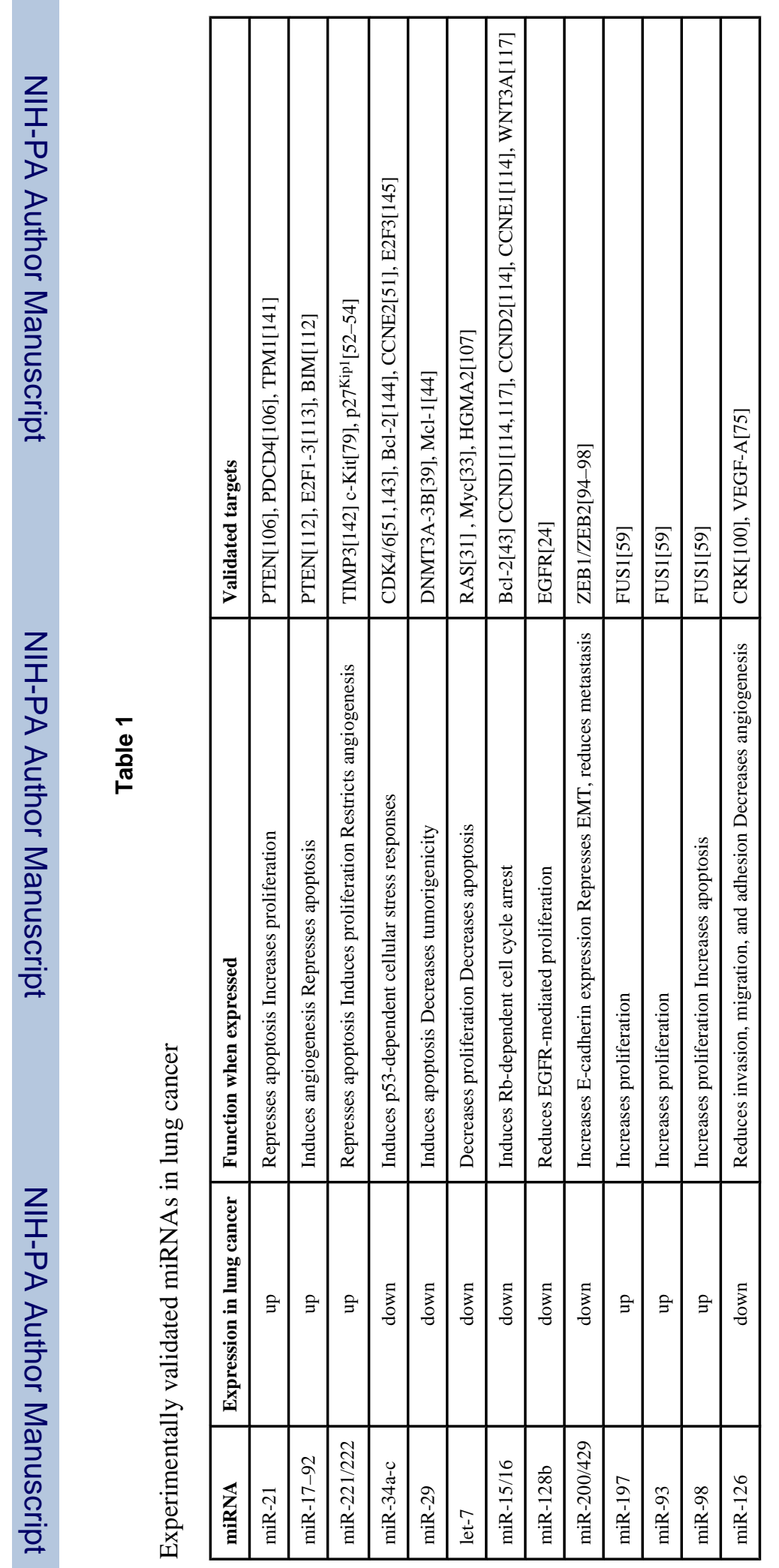

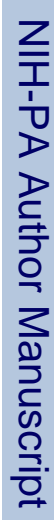

Cancer Metastasis Rev. Author manuscript; available in PMC 2011 March 1. 